Niepełnosprawność. Dyskursy pedagogiki specjalnej

Krystyna Barłóg

Uniwersytet Rzeszowski
„Młode osoby z niepetnosprawnością dzisiaj są świadome dokonujących się zmian"...

W. Dykcik, 2010, Tendencje rozwoju pedagogiki specjalnej.

\title{
Motywacja do aktywności i społecznego uczestnictwa młodych osób z ograniczeniami sprawności
}

Celem niniejszego artykułu jest ukazanie oraz dyskusja nad zmianami jakie dokonują się w podmiotach/jednostkach znajdujących się w kręgu zainteresowań pedagogiki specjalnej, a konkretnie $\mathrm{w}$ grupie młodych osób z niepełnosprawnością. W artykule podjęto próbę wskazania przemian zachodzących w świadomości wymienionej grupy, które bezpośrednio oddziałują na ich zdolność/ kompetencje do definiowania oraz pokonywania barier i wyzwań, z jakimi zwykle borykają się młode osoby z niepełnosprawnością. Doniosłą rolę odgrywa tu także motywacja do edukacji i zatrudnienia, a także różnorodność podejmowanych działań oraz uczestnictwo w życiu społecznym.

Słowa kluczowe: zmiana, motywacja do aktywności i uczestnictwa, młode osoby z niepełnosprawnością

\section{Motivation for activity and social participation of young people with disabilities}

The idea of the presented text is to show and discuss changes undergoing in individuals of special pedagogy, particularly in young people with disabilities. The article attempts to point out changes of consciousness, directly affecting the ability/competence to defining and overcoming the challenges and barriers, young people with disabilities usually face. It also includes the significance of their motivation for education and employment, as well as variety of undertaken activities and participation in social life.

Keywords: change, motivation for activity and participation, young people with disabilities

\section{Próba określenia problemu}

Dokonujące się współcześnie zmiany gospodarcze, społeczno-kulturowe i edukacyjne przyczyniają się do sytuacji, w której proces wchodzenia w dorosłość, stawanie się młodym, dorosłym człowiekiem jest dla niego nie tylko poważnym 
wyzwaniem, ale i problemem. Szczególnie trudny jest to proces w odniesieniu do młodych osób z ograniczeniami sprawności. Zarówno w Polsce, jak i w innych krajach Unii Europejskiej oraz wielu innych stajemy się już uczestnikami demokratycznych zmian zwłaszcza w odniesieniu do osób z niepełnosprawnością, w kierunku integracji i włączania. Prowadzone w szerokim zakresie badania naukowe podejmują próby odpowiedzi na pytanie o stan oraz zakres włączającej przestrzeni dla osób z niepełnosprawnością. Są to pytania typu: czy społeczeństwa, ludzie pełnosprawni wielu krajów udostępniły już autentyczną przestrzeń bez barier i ograniczeń dla osób z niepełnosprawnością? [Bloemers 2004]. Interesujące jest również pytanie: jaka jest $w$ tym zakresie sytuacja indywidualnych osób $\mathrm{z}$ niepełnosprawnością, szczególnie w kontekście ich satysfakcji z życia, życiowego dobrostanu, ich jakości życia, motywacji do rehabilitacji, aktywności w wielu płaszczyznach funkcjonowania oraz pełnionych rolach, ich uczestnictwo i zaangażowanie? To również pytanie o sens i wartości, przekonanie, że mimo niepełnosprawności warto podejmować aktywność, realizować cele, podejmować wysiłek, uruchamiać motywację, w kierunku wprowadzania oczekiwanych zmian, dla projektowania godnego życia, życiowego dobrostanu.

\section{Prezentacja problemu}

W Polsce, w Unii Europejskiej podejmuje się wiele działań mających na celu poprawę warunków, w tym szczególnie w odniesieniu do osób z niepełnosprawnością. Nadal jednak jesteśmy świadkami społecznego odrzucania, wykluczania, marginalizacji, braku pomocy dla osób czy grup wykluczanych. W polityce włączającego, europejskiego społeczeństwa w odniesieniu do osób z niepełnosprawnością szczególnie znaczące są działania, których celem jest zapewnienie wszystkim na równych prawach aktywnego uczestnictwa w życiu społecznym. W odniesieniu do osób z niepełnosprawnością deklaruje się: „konieczność ich aktywizowania oraz aktywnego kształcenia, a także konieczność uwrażliwiania całego społeczeństwa przez rządy, organizacje pozarządowe oraz specjalistów w dziedzinie socjologii i pedagogiki. Konieczność ogólnoeuropejskiego współdziałania ma na celu upowszechnienie „etycznych nastawieñ" $\mathrm{i}$ „spotecznie sprawiedliwych procesów politycznych" [Bloemers 2004, s. 17].

W odniesieniu do pedagogiki specjalnej W. Dykcik [2010, s. 12] przyznaje, że "dynamiczny rozwój wiedzy w naukach społecznych oraz biologicznych spowodował znaczne podniesienie się świadomości osób z niepełnosprawnością, oraz jakościową zmianę świadomości społecznej dostrzeganej w akceptujących i przyjaznych postawach, nastawieniach i zachowaniach otoczenia. Wzmacniają one procesy społecznej akceptacji, integracji i normalizacji życia osób z niepełnospra- 
wnością". Sytuując pedagogikę specjalną między przeszłością a współczesnością J. Wyczesany uważa, że „realizacji zadań w zakresie rehabilitacji służą wieloprofilowe działania o charakterze profilaktycznym, terapeutycznym i socjalnym. Jest to szczególnie istotne w sytuacji zmian jakie mają miejsce w czasach współczesnych" [Wyczesany 2015, s. 13]. Wskazując perspektywy rozwoju pedagogiki specjalnej w kontekście przyjętych paradygmatów tej subdyscypliny pedagogiki A. Krause stwierdza, że „specyfika pomocy osobom z niepełnosprawnością wymaga coraz większych kompetencji, które trudno zapewnić na poziomie dyscypliny ogólnej. Nowym wyzwaniom edukacyjnym, rehabilitacyjnym i społecznym muszą sprostać zarówno osoby bezpośrednio pracujące $\mathrm{z}$ osobami niepełnosprawnymi, jak i osoby, które przez swoje działania mają szansę konstruować ich środowisko" [Krause 2011, s. 7]. W walce z negatywnymi zjawiskami, takimi jak: odrzucenie społeczne, wykluczanie, nauki społeczne i edukacyjne, przybierają formę nauk $\mathrm{w}$ działaniu, a przejawem ich nowych tendencji są prowadzone badania naukowe podłużne dla uchwycenia dokonujących się zmian, i ich wykorzystania w praktyce, dla poprawy warunków, i rozwoju szczególnie w wymiarze europejskim [Bloemers 2004]. Wiele współcześnie prowadzonych już badań naukowych potwierdza, iż możliwości rozwojowo-edukacyjne tych osób są o wiele większe [Wyczesany 2015]. Oczekiwane są więc prakseologiczne, pragmatyczne założenia, i praktyczne zadania w kierunku rozwijania motywacji do aktywności edukacyjnej, zawodowej i społeczno-kulturalnej osób z niepełnosprawnością celem pokonania wielu barier $\mathrm{w}$ drodze do ich autonomii, samorealizacji i społecznej partycypacji, a szczególnie godnej jakości życia.

\section{Model społeczny jako sytuacja wyjściowa do motywacji i uczestnictwa osób z niepełnosprawnością}

Przyjmując społeczny model niepełnosprawności S. Kowalik m.in. dostrzega problem podmiotowego zaangażowania osoby z niepełnosprawnością $\mathrm{w}$ proces rehabilitacji, aktywności i uczestnictwa oraz jej motywację do aktywności i usprawniania. Podkreśla się tu wzrost znaczenia motywacji do rehabilitacji i aktywności $\mathrm{w}$ ramach modelu społecznego. Rehabilitacja $\mathrm{w}$ takim ujęciu prowadzona jest głównie $\mathrm{w}$ naturalnym środowisku życiowym, a osoba niepełnosprawna jest aktywnym elementem procesu usprawniania [Kowalik 2008]. W ujęciu R. Wilińskiego zgodnie ze społecznym modelem niepełnosprawności - niepełnosprawność (disability) to „izolacja i wykluczenie z pełnej partycypacji (aktywności) społecznej powstałe $\mathrm{w}$ wyniku opresji osób z ograniczeniami sprawności ze strony społeczeństwa (struktury współczesnego społeczeństwa) [Wiliński 2010, s. 51]. Zgodnie z tym ujęciem relacja normatywna utraty sprawności odwołuje się nie do 
jednostki, ale do teoretycznie skonstruowanej normy społecznej, zgodnie z którą to społeczeństwo musi się zmienić i dostosować do potrzeb osób z niepełnosprawnością [Wiliński 2010, s. 54].

\section{Motywacja do zmiany, do uczestnictwa i aktywności}

Zmiany społeczno-gospodarcze w edukacji stają się wyzwaniem dla młodzieży z niepełnosprawnością. Motywacja do osobistego rozwoju łączy się z inteligencją społeczną i emocjonalną, motywacją do aktywności i osiągnięć oraz koncentruje się na: potrzebach, umiejętności radzenia sobie ze stresem oraz korelatach osiągnięć edukacyjnych. Istotą są pytania o kierunki działań ludzkich, co pobudza do podejmowania działań dla określonych celów, jaka jest intensywność z którą ludzie realizują określone przez siebie cele, dlaczego jedni ludzie są bardziej wytrwali niż inni, dłużej koncentrują swój wysiłek, jakie są przyczyny wytrwałości, wysiłku? (Osobiste zaangażowanie, presja społeczna, motywacja sukcesu) [por. Klinkosz 2016]. Na przykład w modelu decyzji ryzykownych (Heinza Heckhausena) przyjmuje się, że motywacja sukcesu to wypadkowa konfliktu dychotomicznych tendencji: nadziei na sukces i lęku przed niepowodzeniem. Inaczej mówiąc osoby motywowane obawą przed porażką niechętnie wybierają zadania trudne, chociaż możliwe do osiągnięcia, natomiast osoby motywowane wysokim poziomem potrzeby osiągnięć wybierają cele, zawody wymagające ryzykownych decyzji, osiągają sukces zawodowy i osobisty. Te, u których potrzeby osiągnięć są na niskim poziomie, wybierają cele życiowe, zawody o niskim stopniu ryzyka [Klinkosz 2016]. Nie zgłębiając się w szczegóły mechanizmów motywacyjnych, które są szczególne u osób z niepełnosprawnością, można domniemywać, że młode osoby z ograniczeniami sprawności, ich szczególna faza życia łączy się problemami $\mathrm{w}$ pogodzeniu się z własną niepełnosprawnością, ze znaczącym ograniczeniem planów życiowych, z niechęcią do rehabilitacji, negatywnym ustosunkowaniem się do własnego życia i aktywności, w tym ograniczeniami w planowaniu przyszłości, wyborach celów życiowych oraz wartości.

\section{Dorosłość, dylematy wczesnej dorosłości młodych osób z ograniczeniami sprawności}

Występuje wiele ujęć terminologicznych $\mathrm{w}$ definiowaniu dorosłości. W psychologii E.H. Erikson przyjmuje, że jest to etap w życiu młodego człowieka przypadający na lata 18/20-30/35. Najczęściej przyjmuje się jednak, że jest to okres 
życia przypadający około 20-40 roku życia. Spośród celów, zadań rozwojowych tego okresu życia w psychologii między innymi wymienia się: uzyskanie odpowiedzi na pytanie: kim jestem? kim mogę być? w co chcę się zaangażować? Nabycie zdolności do tworzenia związków, odczuwania miłości, bez ryzyka utraty tożsamości czy - jak proponuje R. Havighurst - budowanie bardziej dojrzałych związków, osiąganie emocjonalnej niezależności od rodziców, bezpieczeństwa i niezależności ekonomicznej, wybór zawodu, osiąganie społecznie niezależnego zachowania, wybór partnera życiowego, start $\mathrm{w}$ rolach rodzinnych i zawodowych, wzięcie na siebie odpowiedzialności, znalezienie grupy towarzyskiej [Brzezińska 2007].

Zadania dla wczesnej dorosłości to: wybór partnera życiowego, uczenie się życia z partnerem, start $w$ rolach rodzinnych, opieka nad dziećmi, zarządzanie domem, start w karierze zawodowej, przyjęcie odpowiedzialności obywatelskiej, znalezienie odpowiedniej grupy towarzyskiej [Brzezińska 2007, s. 235]. Mówiąc o punktualności i niepunktualności podejmowania zadań rozwojowych przyjmuje się, że osoba, która w wieku 40 lat nadal pozostaje na utrzymaniu rodziców, nie realizuje w sposób punktualny takiego zadania rozwojowego, jakim jest podjęcie aktywności zawodowej, i uzyskanie niezależności ekonomicznej, nie podjęła jeszcze innych zadań dorosłości (posiadanie stałego partnera, dzieci) mimo swojego wieku nie jest "petnoprawnym dorostym", a jej społeczna rola jest bliska dla okresu dorastania [Piotrowski 2010, s. 12].

Interesującym jest, że w literaturze psychologicznej [Arnett] współcześnie wskazuje się na konieczność wyodrębniania stadium rozwoju pomiędzy dorastaniem a dorosłością, określając go mianem: wyłaniającej się dorosłości (emergingadulthood). Osoby z wyłaniającej się dorosłości często przyznają, że osiągnęły dorosłość jedynie w pewnych wymaganych dla tego okresu obszarach [ Majewicz 2016]. „Odraczanie podejmowania dorosłych ról społecznych, coraz dłuższy proces edukacji i dłuższe pozostawanie w stanie częściowej przynajmniej zależności od rodziców wiążą się także z subiektywną oceną własnej osoby w wymiarze dziecko/nastolatek-dorosły" [Piotrowski 2010] jako odpowiedź na czasy współczesne, ale i problemy, bariery jakie powstają w sytuacji niepełnosprawności.

Zaprezentowane zadania rozwojowe są utrudnione w przypadku młodych osób z ograniczeniami sprawności. W odniesieniu do młodych osób z ograniczeniami sprawności można wskazać na wiele problemów nie tylko wynikających z okresu dorosłości, lecz szczególnie realizacja celów, zadań rozwojowych jest tu utrudniona ze względu na stan zdrowia i niepełnosprawność, obraz samego siebie, uruchamiane mechanizmy obronne, pytania o sens czy bezsens życia i wartości, trudności w edukacji i zatrudnianiu, relacje z innymi oraz z płcią przeciwną. „Poczucie dorosłości osób niepełnosprawnych silniej niż wśród osób zdrowych wiąże się z oceną własnych cech i aktywnością społeczną" [Piotrow- 
ski 2010]. Analizując dylematy dorosłości młodych osób z ograniczeniami sprawności można odnieść się do zaproponowanych zadań i dylematów wczesnej dorosłości według Levinsona, który wyodrębnia następujące obszary: dylemat teraz vs przyszłość, dylemat zależność vs niezależność, dylemat eksploracja vs zaangażowanie, dylemat praca vs rodzina [Borawski 2016].

KIM JESTEM?

TERAZ? - PRZYSZŁOŚĆ?

ZALEŻNOŚĆ? - NIEZALEŻNOŚĆ?

\section{DYLEMATY DOROSŁOSCI OSÓB Z NIEPEŁNOSPRAWNOŚCIĄ}

EKSPLORACJA? - ZAANGAŻOWANIE?

PRACA? - RODZINA?

\section{ŻYCIE SPOŁECZNE?}

Rys. 1. Dylematy wczesnej dorosłości osób z ograniczeniami sprawności Źródło: Opracowanie własne na podstawie [Borawski 2016].

Wszystkim tym problemom czy dylematom, ale i wyzwaniom towarzyszy wiele konfliktów, lęków, zagrożeń wynikających z różnych grup nacisków, a zwłaszcza społecznego.

Dylemat: TERAZ vs PRZYSZłOŚĆ - trudne wkraczanie w dorosłość osób $\mathrm{z}$ niepełnosprawnością

\section{SFORMUŁOWANIE}

- Ja realne - ocena szans

\section{NASTAWIENIA}

- MARZENIA scenariusze realizacji najważniejszych celów

- Emocje między Z. a N.

\section{MOTYWACYJNEGO}

- Ja możliwe

Rys. 2. Dylematy dorosłości między teraźniejszością a przyszłością Źródło: Opracowanie własne na podstawie [Borawski 2016]. 
Młode osoby z ograniczeniami sprawności mają takie same cele, plany oraz marzenia, problemem jest uzyskanie efektów w ich realizacji. Trudno jest młodym osobom z niepełnosprawnością doświadczyć, że są dorosłymi zanim będą mieć własne mieszkanie, oczekiwaną pracę, niezależność ekonomiczną, większą sprawność czy bardziej oczekiwany stan zdrowia. Jednak z badań wynika, że decydujące jest tu uznanie siebie jako osoby biorącej odpowiedzialność za siebie, podejmującej samodzielne decyzje, niezależnej finansowo, czyli to wszystko co jest zmianą postrzegania siebie [Piotrowski 2016, s. 18]. Mimo wielu dylematów i problemów coraz więcej młodych osób z ograniczeniami sprawności podejmuje się tego rodzaju wyzwań. W sformułowaniu marzenia następuje poszukiwanie możliwości oraz scenariuszy dla określenia nastawienia motywacyjnego z oceną szans na realizacje marzeń, i możliwości realizacji. Emocje jakie temu procesowi towarzyszą są między zniechęceniem a nadzieją [Borawski 2016].

Dylemat: ZALEŻNOŚĆ: vs NIEZALEŻNOŚĆ - trudne wkraczanie w dorosłość

W trakcie realizacji zadań, celów oraz marzeń życiowych młoda osoba z ograniczeniami sprawności jest postawiona przed dylematami pozostania w zależności zwłaszcza emocjonalnej, ekonomicznej od rodziców, rehabilitantów czy lekarzy dotyczących wyborów własnej drogi życia. Pytanie kim jestem staje się pytaniem kim być? Kim mogę zostać? „W relacjach ludzi niepełnosprawnych często pojawiają się opisy sytuacji wskazujące na ich infantylizowanie - informacja o ich stanie zdrowia bywa przekazywana rodzinie osoby niepełnosprawnej, a nie samemu zainteresowanemu" [Benedyktyńska, Rycielski 2010, s. 7]. W sytuacji niepowo-

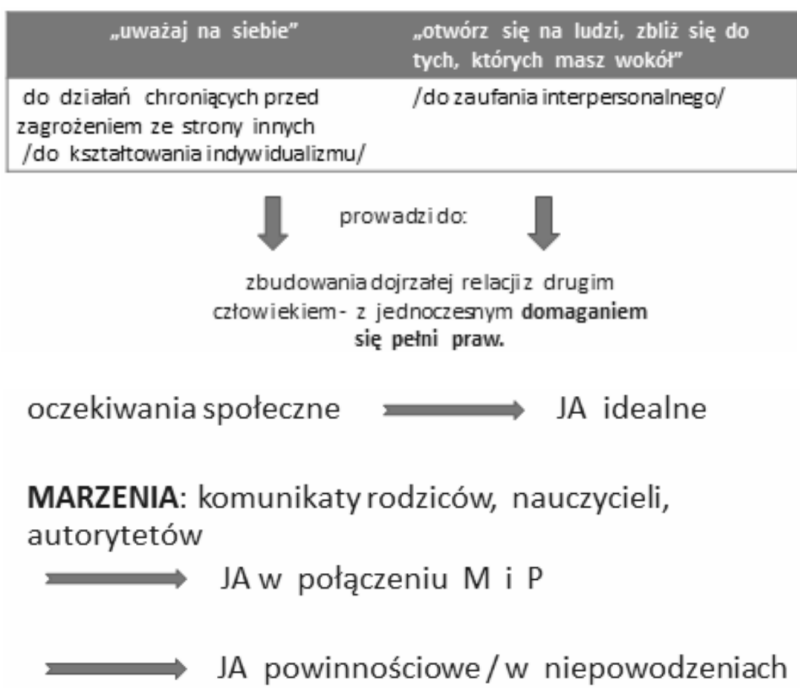

Rys. 3. Między zależnością a niezależnością

Źródło: Opracowanie własne na podstawie [Borawski 2016]. 
dzeń młoda osoba z niepełnosprawnością jeszcze bardziej staje się uzależniona od innych, rodziców, opiekunów, specjalistów. Nadmierne wsparcie i pomoc może pogłębiać sytuację zależności oraz ograniczać autonomię i podmiotowość młodych osób z ograniczeniami sprawności. Oczekiwana jest dojrzała relacja z osobą z niepełnosprawnością.

Dążenie do autonomii u młodych osób z ograniczeniami sprawności jednocześnie łączy się z lękiem przed utratą stabilizacji i poczucia bezpieczeństwa, niepewności, potrzebą podmiotowości, uczestnictwa, odkrywania różnych obszarów aktywności, zaangażowania, poszukiwania stabilizacji i eksploracji, wzmacniania tego co jest już osiągnięte i pewne, bezpieczne, ale i poszukiwania twórczych rozwiązań.

Dylemat: PRACA vs RODZINA. Trudne wkraczanie w dorosłość

Dla młodych osób wkraczanie w dorosłość jest dzisiaj trudnym wyzwaniem zwłaszcza w sytuacji poszukiwania pracy, ze względu na wysokie wskaźniki bezrobocia. W tych płaszczyznach szczególnie zaobserwować można odraczanie, opóźnienie realizacji zadań rozwojowych. Warto nadmienić, że tylko co czwarta osoba z niepełnosprawnością posiada partnera życiowego, a i wszelkie związki $\mathrm{w}$ tej populacji, $\mathrm{w}$ tym także formalne, są szczególnie narażone na rozpad częściej aniżeli u osób pełnosprawnych. Młode osoby z niepełnosprawnością obawiają się utraty ukochanej osoby, obawiają się litości z jej strony i poświęcenia. W Polsce jedynie około $20 \%$ osób z niepełnosprawnością fizyczną zakłada rodzinę. Zdecydowana większość z tej populacji nie zakłada rodziny, nie posiada dzieci, nie ma stałego partnera, najczęściej pozostaje i mieszka z rodzicami [Kirenko 1995; Majewicz 2016; Barłóg 2016].

Młode osoby z niepełnosprawnością doświadczają dwojakiego rodzaju barier: trudności na rynku pracy, ale i specyficznych barier związanych z ich niepełnosprawnością. Przejście od edukacji do pracy jest jednym z najtrudniejszych momentów dla młodych osób niepełnosprawnych. Jeśli zakończy się ono sukcesem, jest podstawą do efektywnego dorosłego ich życia. Najczęściej jednak kończy się porażką, co w znaczącym stopniu obniża poczucie ich własnej wartości, wprowadza lęk i bezradność, poczucie niepewności i w dalszej perspektywie prowadzi do syndromu wyuczonej bezradności, wpływając na kolejne decyzje nie tylko zawodowe, ale i osobiste, rodzinne, obniżając ich marzenia na godną jakość życia, w tym oczekiwany status społeczno-ekonomiczny, aktywność, kreatywność w wypełnianiu wielu dorosłych ról i zadań dorosłości [Struck-Peregończyk 2016]. Jest to też okres szczególnie trudnych decyzji i dylematów dla młodych osób z niepełnosprawnością, zwłaszcza jeżeli chodzi o takie wyzwania, ale i marzenia, takie jak: założenie własnej rodziny, opuszczenie domu rodzinnego czy podjęcie aktywności edukacyjnej, społecznej, a w końcu i zawodowej. Badania potwierdzają, że młode osoby z niepełnosprawnością częściej doświadczają 
długotrwałego bezrobocia, i jednocześnie wcześniej kończą edukację, mimo, iż wzrasta wskaźnik młodych osób z niepełnosprawnością studiujących w uczelniach wyższych. Niepełnosprawnej młodzieży rzadziej, oraz w czasie późniejszym, udaje się uniezależnić od rodziny pochodzenia, i w końcu założyć własną rodzinę [Piotrowski 2010].

Szczególnym problemem jest zbyt opiekuńcza rodzina, która często obniża lub uniemożliwia decyzje realizacji zadań rozwojowych przypisywane okresowi dorosłości. Badania potwierdzają również, że znaczący odsetek młodych osób $\mathrm{w}$ tym wieku nadal mieszka $\mathrm{z}$ rodzicami, nie pracuje i nie wchodzi $\mathrm{w}$ żadne związki partnerskie, co potwierdza niskie ich poczucie dorosłości [Piotrowski 2010], ale i poczucie bycia przez nich w pełni osobą dorosłą. Szczególnie ważnym obszarem wchodzenia w dorosłość jest aktywność zawodowa. Praca zawodowa jest swoistą formą ich rehabilitacji, ale i tak oczekiwanej w dorosłości niezależności finansowej oraz budowania $\mathrm{w}$ nich poczucia przydatności, niezależności, poczucia własnej wartości. Nadaje ona również osobie z niepełnosprawnością status bycia „osoba dorostą". Realizacja ról zawodowych staje się podstawą do realizacji kolejnych zadań rozwojowych okresu dorosłości [Piotrowski 2010; Struck-Peregończyk 2016].

\section{Znaczenie edukacji i zatrudniania w procesie budowania gotowości do zmiany}

Zmiana jaka następuje szczególnie w odniesieniu do młodych osób z niepełnosprawnością, zgodnie z teorią dotycząca zmiany, jest procesem przechodzącym przez kolejne fazy (zob. rys. 4) i prowadzi do naruszenia dotychczasowej sytuacji osoby z niepełnosprawnością oraz jej środowiska. Jest to proces trudny, w którym ma miejsce naruszenie status quo podmiotu i jego przestrzeni, a także powoduje opór i niepewność czy lęk przed zmianą. Wymaga diagnozy czynników zarówno ryzyka, jak i zasobów podmiotu, aby rozpoczynać działania dotyczące zmian. Od młodych osób z niepełnosprawnością zmiana będzie wymagała ogromnego wysiłku, może obniżać poczucie własnej wartości, nastroju, poczucie niepewności, oraz budzić wiele wątpliwości. Wszystkim tym trudnościom oraz szczególnym potrzebom w okresie zmiany musi pomóc edukacja, szczególnie w kontekście wspierania przeświadczenia o potrzebie zmian, a także potwierdzania jej zasobów, budowania jej poczucia własnej wartości, i ukazywania "białych plam” jako przestrzeni do zmiany [Rosińska 2008; Egan 2002]. Dla młodych osób z niepełnosprawnością szczególnym wyzwaniem, nadzieją na zmianę ich sytuacji dotyczącej trudnej przyszłości jest edukacja, 


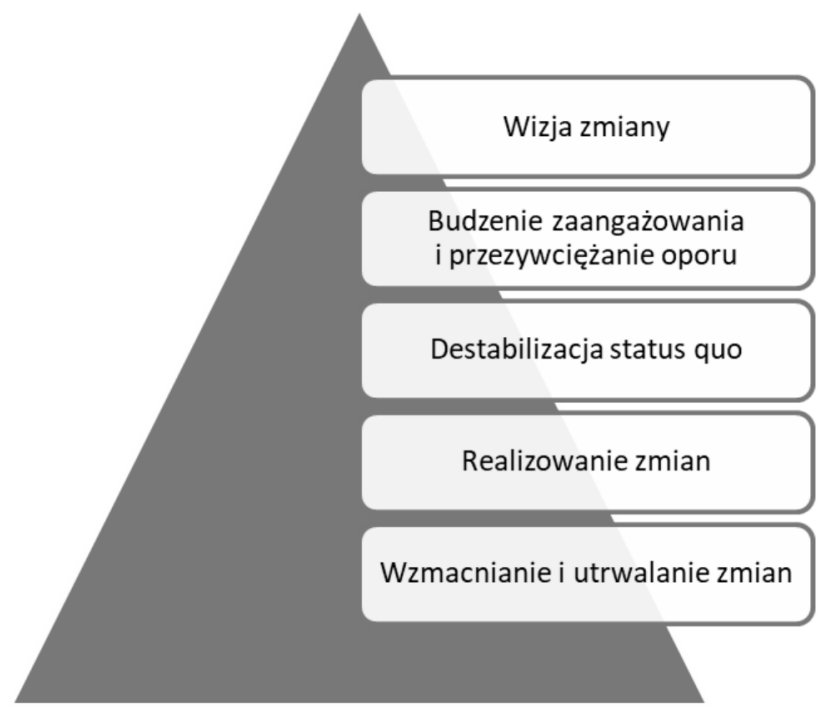

Rys. 4. Zjawiska i etapy w procesie zmiany

Źródło: [Rosińska 2008].

również na poziomie akademickim, wejście w rolę studenta, kontakty w społeczności akademickiej, i w końcu nabywanie profesjonalnych kompetencji zawodowych, uzyskanie stopnia magistra czy nawet doktora, jako nie tylko szansy

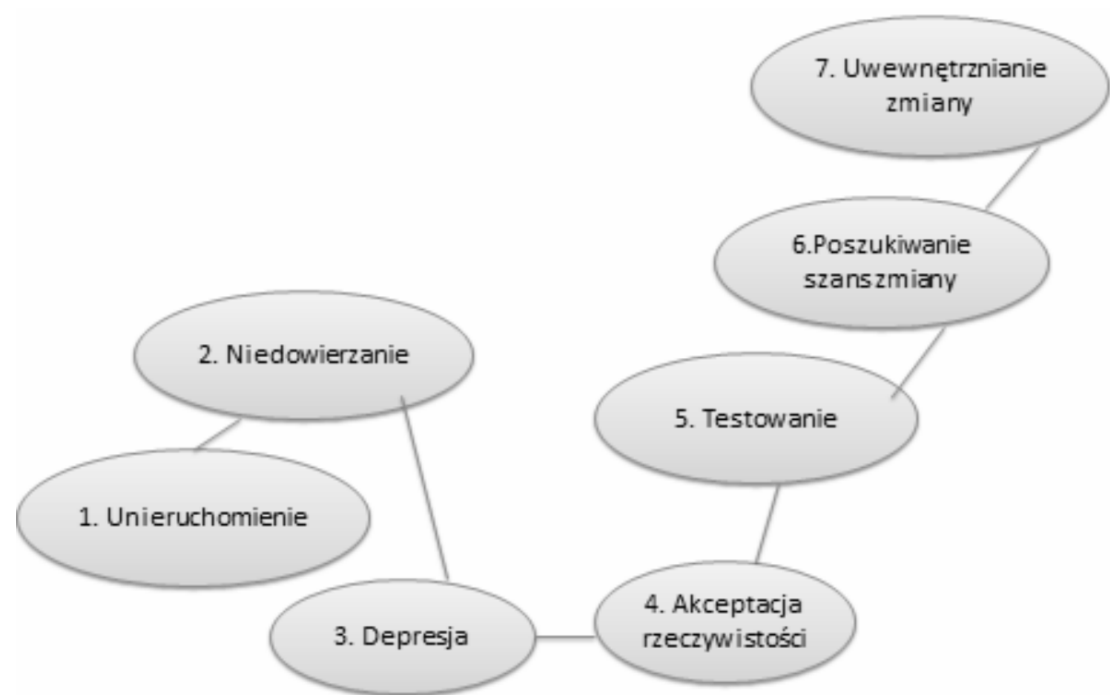

Rys. 5. Poczucie własnej wartości podmiotu w procesie zmiany Źródło: [Clarks1997, za: Rosińska 2008]. 
na zatrudnienie zgodne z wyuczonymi kwalifikacjami, ale poczucie autonomii, niezależności, poczucie własnej wartości.

W przezwyciężaniu niepewności i lęku o przyszłość, ale i lęku związanego z mechanizmami marginalizacji i wykluczania, w budowaniu gotowości do zmiany szczególnego znaczenia nabiera samoocena, potrzeba budowania poczucia własnej wartości młodych osób z niepełnosprawnością.

U osób z niepełnosprawnością pojawia się wiele mechanizmów obronnych, takich jak: zaprzeczanie, regresja, fiksacja, przemieszczenie, projekcja, sublimacja, racjonalizacja, kompensacja oraz inne. Powodem są sytuacje trudne, które utrudniają lub udaremniają realizację celów i dążeń, prowadząc do frustracji, braku szacunku do siebie, depresji, autoagresji z uczuciami nienawiści do siebie w sytuacjach bezradności. Tego rodzaju mechanizmy nie redukują negatywnych emocji, lęku, ale prowadzą do samooszukiwania się, zaprzeczania. U osób z niepełnosprawnością ruchową można dostrzec symptomy posttraumatycznego dystresu. Edukacja i sukcesy w zatrudnieniu mogą wyzwalać pozytywne mechanizmy, takie jak: działalność literacką, malarską, muzyczną, aktywność artystyczną i społeczną, samopomocową, które pozwalają nadać ich życiu sens [Majewicz 2016; Barłóg 2016a].

Z danych GUS z 2011 roku dotyczących wykształcenia młodych osób z niepełnosprawnością na Podkarpaciu wynika, że wzrasta poziom wykształcenia osób z niepełnosprawnością: policealne/średnie (33,2\%), gimnazjalne, podstawowe $(32,4 \%)$, zasadnicze zawodowe $(18,3 \%)$, wyższe $(10,7 \%)$, podstawowe nieukończone, bez wykształcenia (5,4\%) [Struck-Peregończyk 2016]. Bardzo powoli zmienia się sytuacja zatrudnienia młodych osób z niepełnosprawnością. Mimo wykształcenia młodzi niepełnosprawni nadal doświadczają wielu barier ograniczających możliwości ich zatrudnienia. Do przyczyn nieposzukiwania pracy przez młode osoby z niepełnosprawnością na Podkarpaciu, na podstawie prowadzonych rozległych badań M. Struck-Peregonczyk, [2016] m.in. należy wymienić: stan zdrowia uniemożliwiający zatrudnienie, lęk spowodowany możliwością utraty renty lub innych świadczeń społecznych, plany związane z dalszą ich edukacją, niewiedza jak szukać pracy, odłożenie w czasie decyzji o poszukiwaniu pracy, przewidywane trudności wynikających z dojazdu do pracy, brak zgody rodziny, inne obowiązki rodzinno-domowe, przekonanie o braku pracy zgodnej z wykształceniem, obawa przed znalezieniem pracy odpowiednio wynagradzanej, zniechęcenie bezskutecznym poszukiwaniem pracy. Wielu młodych osób z niepełnosprawnością rezygnuje z poszukiwania zatrudnienia, aktywności zawodowej. Jest wiele przyczyn takiego stanu bezradności i niewiary w szansę pełnienia roli zawodowej, mimo iż $\mathrm{w}$ tym regionie realizowanych jest wiele projektów unijnych przygotowujących z wykorzystaniem wykwalifikowanych trenerów pracy do podjęcia aktywności zawodowej. 


\section{Zakończenie}

Zmiana sytuacji młodych osób z niepełnosprawnością jest długofalowym procesem pełnym jeszcze wielu barier, ograniczeń, ale i trudności, i łączy się często z oporem ze strony samych młodych osób z niepełnosprawnością, u którym mimo trudności wzrasta świadomość praw i potrzeba aktywności, autonomii i uczestnictwa. Przyczyn powolnego procesu zmian należy nadal poszukiwać w przestrzeni społecznej osób z niepełnosprawnością, oraz w nierównomiernej nadal jeszcze ofercie pomocy i wsparcia. $Z$ badań Benedyktyńskiej i Rycielskiego [2010] wynika, że występują jeszcze niekiedy procesy stereotypizacji i stygmatyzacji, które w sposób znaczący obniżają samoocenę oraz aktywność społeczną i zawodową młodych osób z ograniczeniami sprawności. Badania własne potwierdzają, że młodzież studiująca z niepełnosprawnością jest silnie motywowana do aktywności i uczestnictwa w sytuacji wsparcia kolegów, sympatii, wykładowców, jednak poważnym problemem dla niej jest lęk o przyszłość, lęk przed samotnością, i nadal występujące ograniczenia oraz bariery.

\begin{tabular}{|c|c|c|}
\hline Bariery egzystencjalne & Bariery zdrowotne & Bariery psychospołeczne \\
\hline Depresja & Lęk & Wstyd \\
\hline Niepewność & Niska samoocena & $\begin{array}{c}\text { Brak przekonaniao własnej } \\
\text { skuteczności }\end{array}$ \\
\hline
\end{tabular}

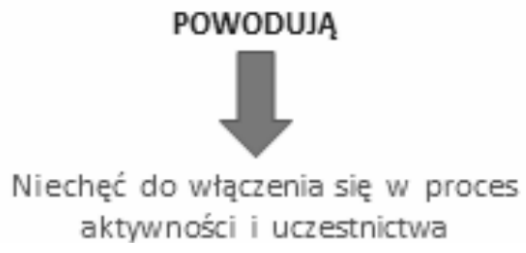

Rys. 6. Położenie życiowe młodych osób utrudniające zaangażowanie w rehabilitację Źródło: Opracowanie własne na podstawie [Kowalik 2008, s. 20].

Negatywny odbiór społeczny powoduje obniżony nastrój, podwyższony lęk, myśli negatywne, wysoki poziom stresu, nasilone objawy psychosomatyczne, i w konsekwencji trudności w funkcjonowaniu społecznym, intelektualnym oraz zawodowy. A Krause [2016, s. 17] jako powody takiego stanu podaje brak rozwiązań systemowych dotyczących pracy z dorosłymi osobami z niepełnosprawnością. Jak pisze „dalsze źródła upośledzonej dorosłości leżą w samym systemie organizacji wsparcia dla osoby dorosłej. Podstawowym jej problemem (oprócz opisywanej jednolitej formy) jest nierównomierność dostępu do różnorodnego wsparcia w miastach, miasteczkach i na wsi". 
Wyzwaniem jest tu poszukiwanie możliwości, podnoszenie poczucia własnej wartości oraz doznawanie emocji pozytywnych, które są podstawą budowania gotowości do zmiany, radzenia sobie z problemami. W toku pozytywnej rehabilitacji warto rozwijać te pozytywne cechy oraz kompetencje. Aktywizowanie młodych osób z niepełnosprawnością, ich silna motywacja, zaangażowanie się $\mathrm{w}$ proces rehabilitacji, uczestnictwa nadaje ich życiu sens. Problem motywacji osób z niepełnosprawnością wydaje się szczególnie interesujący w sytuacji postępujących zmian inkluzyjnych, ale bywa, że czasem wykluczających. M. Wiliński, prezentując modelowe strategie pomocy osobom z ograniczeniami sprawności, domaga się systemowych działań interwencyjnych, społecznych oraz wiedzy społecznej na temat autentycznych i podmiotowych potrzeb młodych osób z niepełnosprawnością. W strategiach pomocy zwraca się w kierunku: medykalizacji, usprawniania i włączania [Wiliński 2010].

\section{Bibliografia}

Barłóg K. (2016), Kapitat społeczny a problemy, kompetencje i cele życiowe młodzieży z ograniczeniami sprawności [w:] M. Marmola, A. Wańczyk-Welc, Kompetencje życiowe młodych dorostych, Rzeszów.

Barłóg K. (2016a), Life Goals and Sense of Meaning or Meaninglessness of Lifein Young People, „International Journal of Psycho-Educational Sciences” vol. 5, issue 2, September.

Benedyktyńska S., Rycielski P. (2010), Kim jestem? Przecizwdziałanie stereotypizacji i stygmatyzacji osób z ograniczeniami sprawności, Warszawa.

Bloemers W. (2004), Europejski wymiar społecznego wtaczania: nowe aspekty i perspektywy integracji społecznej osób niepetnosprawnych [w:] W. Dykcik. A. Twardowski, Wspomaganie rozwoju i rehabilitacja dzieci z genetycznie uwarunkowanymi zespotami zaburzeń, Poznań.

Borawski D. (2016), Dylematy tożsamościowe wczesnej dorostości z perspektywy dialogowej [w:] M. Marmola, A. Wańczyk-Welc, Kompetencje życiowe młodych dorostych, Rzeszów.

Brzezińska A.I. (2007), Społeczna psychologia rozwoju, Warszawa.

Dykcik W. (2010),Tendencje rozwoju pedagogiki specjalnej. Osiagnięcia naukowe i praktyka (z perspektywy 50-lecia pracy pedagogicznej z osobami z niepetnosprawnościa, Poznań.

Egan G. (2002), Kompetentne pomaganie, Poznań.

Kirenko J. (1995),Niektóre uwarunkowania psychospotecznego funkcjonowania osób z uszkodzeniem rdzenia kręgowego, Lublin.

Klinkosz W. (2016), Relacje interpersonalne i motywacja osiagnięć studentów różnych kierunków studiów [w:] M. Marmola, A. Wańczyk-Welc, Kompetencje życiowe młodych dorostych, Rzeszów.

Kowalik S. (2008), Motywacja do rehabilitacji osób w podeszlym wieku, „Forum. Kwartalnik Pedagogiczno-Terapeutyczny", nr 1-2.

Krause A. (2016), Dorostość w niepetnosprawności intelektualnej, „Niepełnosprawność. Dyskursy pedagogiki specjalnej", $\mathrm{nr} 24$.

Krause A. (2011, Wstęp, „Niepełnosprawność. Perspektywy i drogi rozwoju pedagogiki specjalnej", nr 5 . 
Majewicz P. (2016), Wybrane aspekty psychospołecznego funkcjonowania osób z niepełnosprawnością ruchową w okresie wczesnej dorostości [w:] M. Marmola, A. Wańczyk-Welc, Kompetencje życiowe młodych dorostych, Rzeszów.

Piotrowski K.(2010), Wkraczanie w dorosłość. Tożsamość i poczucie dorosłości młodych osób z ograniczeniami sprawności, Warszawa.

Rosińska A. (2008), Znaczenie edukacji w procesie budowania gotowości do zmiany [w:] J. Hoffman, Znaczenie edukacji w procesie readaptacji osób wykluczonych w kontekście doświadczeń projektu KPU-NSD, Poznań.

Struci-Peregończyk M. (2016), Młode osoby niepełnosprawne. Aspiracje zawodowe a rzeczywistość [w:] M. Marmola, A. Wańczyk-Welc, Kompetencje życiowe młodych dorosłych, Rzeszów.

Wiliński M. (2010), Modelowe strategie pomocy osobom z ograniczeniami sprawności: medykalizacja, usprawnianie - wtączanie [w:] A.I. Brzezińska, R. Kaczan, K. Smoczyńska, Diagnoza potrzeb i modele pomocy dla osób z ograniczeniami sprawności, Warszawa.

Wyczesany J. (2015), Przeszłość a dzień dzisiejszy pedagogiki specjalnej [w:] K. Barłóg, Wsparcie wczesnorozwojowe dzieci zagrożonych niepetnosprawnościa i niepetnosprawnych, Rzeszów. 